\title{
The dynamics of landscape change and snow geese in mid-continent North America
}

\author{
KENNETH F. ABRAHAM*, ROBERT L. JEFFERIES † and RAY T. ALISAUSKAS \\ *Ontario Ministry of Natural Resources, 300 Water Street, Peterborough, ON, Canada K9J 8M5, †Department of Botany, \\ University of Toronto, 25 Willcocks St., Toronto, ON, Canada M5S 3B2, †Canadian Wildlife Service, Prairie and \\ Northern Wildlife Research Centre, 115 Perimeter Road, Saskatoon, SK Canada S7N 0X4
}

\begin{abstract}
The Mid-Continent Population of the lesser snow goose, which breeds in the eastern and central Canadian Arctic and sub-Arctic, and winters in the southern United States and northern Mexico has increased 5-7\% annually from the late 1960s to the mid-1990s, largely because of increased survival in response to an agricultural food subsidy. The rise in numbers complements the increased use of nitrogen fertilizers and a corresponding rise in yields of rice, corn, and wheat along the flyways and on the wintering grounds. In sub-Arctic migration areas and at Arctic breeding colonies, foraging by high numbers of birds has led to loss of coastal vegetation, adverse changes in soil properties and the establishment of an alternative stable state of exposed sediment, which can be detected with LANDSAT imagery. At a local scale, gosling growth, size and survival decreased in affected areas and other taxa have been adversely affected. The food subsidy on wintering and migration areas appears insufficient to meet reproductive demands as foraging in spring continues to occur on southern Hudson Bay staging and nesting areas. The recent introduction of liberal hunting regulations may reduce population size in the near term, but the revegetation of these coastal ecosystems will take decades to achieve. The present pattern of vegetation loss in these Arctic coastal systems is likely to continue in the forseeable future.
\end{abstract}

Keywords: agricultural crops, Arctic salt and freshwater marshes, fertilizer use, lesser snow geese, spring hunt

Received 2 July 2004; revised version received and accepted 15 October 2004

\section{Introduction}

Landscape changes in one biome indirectly can impact events in another biome via their effects on migratory species (Webster et al., 2002). Since World War II, agricultural practices throughout mid-continent North America and in Europe have undergone profound changes (Van Roomen \& Madsen, 1992; Whitney, 1994; Shrubb, 2003). Simultaneously, conservation practices have created widespread wildlife refugia (US Fish and Wildlife Service (USFWS), 2001). Together, these have altered patterns of land use on a scale that has affected the feeding habits, survival, and migratory patterns of bird populations, especially the Anatidae (ducks, geese, and swans) (Van Eerden et al., 1996). Many of these

Correspondence: Robert L. Jefferies,

e-mail: jefferie@botany.utoronto.ca species breed in boreal, sub-Arctic, or Arctic regions and winter at more southerly latitudes.

In the case of the lesser snow goose (Chen caerulescens caerulescens A.O.U.), agricultural changes in the midcontinent and the establishment of refugia have inadvertently adversely affected sub-Arctic and Arctic terrestrial ecosystems via connectivity of their migratory behaviour (Jefferies et al., 2004). Between the 1920s and 1950s, nesting areas, migration routes, staging sites, and wintering areas for Mid-Continent lesser snow geese were relatively well-defined (Mcllhenny, 1932; Soper, 1942; Cooch, 1955). However, in the mid-1950s, their geographic distribution began to undergo great change because lesser snow geese exhibited considerable flexibility in their use of wintering, breeding, and migratory areas closely linked to the changes in agricultural and conservation practices mentioned above (Alisauskas et al. 1988; Alisauskas \& Ankney, 1992; Abraham \& Jefferies, 1997; Alisauskas, 1998; 
Krapu \& Schultze, unpublished results). One of the most dramatic examples of this flexibility has been the shift of the Mid-Continent Population from its historical winter dependence on the salt and brackish marshes of the Gulf of Mexico to its use of the irrigated rice prairies of Texas and Louisiana (Lynch et al., 1947; Bateman et al., 1988) and subsequently other agricultural crops farther north beyond these states. Snow geese of the Mid-Continent Population now feed on agricultural land for much of the winter and during migration (Alisauskas et al., 1988; Alisauskas, 1998). Response of this population to environmental change can be used as an indicator of similar ecological responses that may be occurring in other goose populations (e.g. whitefronted geese, Anser albifrons, Krapu et al., 1995, and Canada geese, Rusch et al., 1995).

Here, we review the current status of the MidContinent Population of lesser snow geese and trace developments in agriculture and in the establishment of wildlife refugia in the midcontinent since the first third of the 20th century. We examine response of lesser snow geese to land-use changes, particularly in bird distribution, habitat choices, and timing and routes of migration. We also document past and present impacts of growth by this population on staging and breeding areas in the sub-Arctic and Arctic. We put our conclusions in a wider ecological context of the effects of global change on these northern systems.

\section{Methods}

Coordinated mid-winter goose counts have been conducted by the states of the Central and Mississippi Flyways and the US Fish \& Wildlife Service since the early 1950s. These counts were averaged for 5-year periods for each state and for zones within states and plotted to show population growth and patterns of distributional change over time. The Canadian Wildlife Service has conducted photographic inventories of snow goose nesting colonies since the 1970s. These surveys provide a minimum estimate of the total MidContinent Population breeding geese, their relative distribution in summer, and an independent estimate of growth rate. In recent years, numbers of Ross's Geese (Chen rossii A.O.U.) have steadily increased in the Mississippi and Central Flyways in areas used by the Mid-Continent Population of lesser snow geese (Kelley et al., 2001). In addition, this smaller white goose has begun to breed in coastal marshes where lesser snow geese have traditionally nested but are accounted for separately in estimates of nesting populations (Kerbes et al., 2005). However, this is a very recent development with respect to the geographical areas over which the Mid-Continent Population of lesser snow geese mi- grates and breeds (e.g. Ross's geese were first recorded in hunter harvests in 1974 in the Central Flyway and 1982 in the Mississippi Flyway). As recently as 2001, Ross's geese made up only $2.3 \%$ of combined total of Ross's and lesser snow geese wintering in Louisiana and $5.7 \%$ of birds present in Texas in winter (Kelley et al., 2001). The interactions between modern agriculture and the Mid-Continent Population of lesser snow geese reflect changes that commenced earlier. Hence, we do not think there are serious confounding effects because of the increasing but still limited presence of Ross's geese in the areas assessed in this paper. Agricultural data were obtained from the US Department of Agriculture, National Agricultural Statistics Section, for the period 1950-2002, for the wintering range. We obtained data on area planted and harvested, and yield for major crops used by geese (corn, rice, wheat) and for soybean which occupies a major portion of agricultural land in the Mid-Continent Population's range but is used little by snow geese. Data on total nitrogen fertilizer consumed in each state for 1950-2002 were obtained from The Fertilizer Institute at the University of Kentucky (D. Terry). We determined 5year trends for comparison with crop and goose data. US National Wildlife Refuges were created, in part, for use by wintering snow geese beginning in the 1930s. Data on area of refuges and years of establishment were obtained from various US Fish \& Wildlife Service web sites.

\section{The Mid-Continent Population of lesser snow geese}

A coordinated mid-winter survey in the Mississippi and eastern Central Flyways has been used as an index for abundance of the Mid-Continent Population. Trends in this index show that the Mid-Continent Population was relatively stable from 1950 to about 1970 (Dzubin et al., 1975) but increased fourfold from 1970 to a peak in 1998 (Fig. 1). The index appears to have stabilized since then, following introduction of extended regular hunting seasons with an increased bag limit in 1999, use of electronic calls, and special spring conservation seasons in the United States and in parts of Canada in 2001 to control population growth.

The index underestimates the actual number of breeding birds in the spring population by approximately half (Dzubin et al., 1975; Kerbes, 1975; Boyd et al., 1982). Although the population has grown and expanded its winter range, each state tracks these increases in its annual surveys. Doubling the winter index (Fig. 1) gives estimates of the breeding population of nearly 6 million birds in 1998, and above 5 million in 2003, after 4 years of the spring hunt. Reproductively immature yearlings and subadults add up to $40 \%$ more birds to the spring population. 


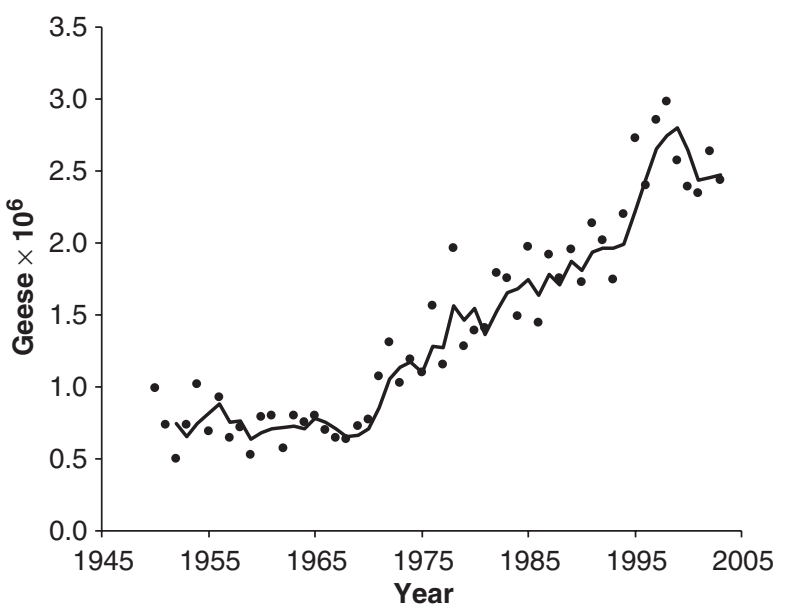

Fig. 1 Mid-Winter Index of lesser snow geese and Ross's geese in the Mid-Continent Population, 1950-2003. Solid line is based on a 3-year running average. Data from the Mississippi and Central Flyways courtesy of K. Gamble, US Fish \& Wildlife Service, Columbia, Missouri and D. Sharp, US Fish \& Wildlife Service, Denver, CO.

The rise in numbers since 1970 does not appear to have been caused by a reduction in harvesting. There was an increase in the total harvest for the Mississippi and Central flyways and in Canada as the population growth accelerated. Between 1970 and 1998, the total number of birds harvested annually fluctuated between 300000 and 700000 (Cooke et al., 1999; Kruse \& Sharp, 2002), which was greater than the average (284000) in the preceding decade when the population size was stable (1960-1969). However, from 1970 to 1998, the proportion of the postbreeding population that was harvested failed to rise at the same rate as the overall growth of the Mid-Continent Population, thus the impact of hunting on overall mortality likely declined. Recent declines in the winter index may signal a halt in growth, as a result of regulatory changes described earlier, or changes in agriculture (see Caveat) but more time is needed for a proper assessment of the effects of these changes.

The distribution of the Mid-Continent Population within its central and eastern Canadian Arctic breeding range also has changed over the last 60 years. In the 1940s, nearly all known birds of the Mid-Continent Population bred north of $60^{\circ} \mathrm{N}$, but by 1973 and 1979, only $57 \%$ and $61 \%$, respectively, bred there (Kerbes, 1975; USFWS, 2001). This change was a consequence of the establishment of new southern Hudson Bay colonies where in years with a late spring thaw, northern-hatched birds stayed to nest (Hanson et al., 1972; MacInnes \& Kerbes, 1987; Abraham et al., 1999). However, since the 1970s, the southward shift has reversed, indicated by the growth of northern colonies, and a decline in recruitment on the west coast of Hudson Bay (Kerbes, 1983; Kerbes et al., 2005), so that by $1997,80 \%$ of lesser snow geese nested north of $60^{\circ} \mathrm{N}$. The latter decline may be related to a depleted resource base in these coastal marshes (Kerbes et al., 1990; Abraham \& Jefferies, 1997).

\section{Crop production, fertilizer use and growth of the Mid-Continent Population}

Boyd et al. (1982) suggested that increased numbers of Mid-Continent Population snow geese were linked to increases in crop production and to changes in agricultural practices. Data for yield of rice and corn, total area planted with these crops and fertilizer use are shown in Fig. 2, and similar data for wheat and soybean are shown in Fig. 3 for selected states. Geese feed on waste corn, rice and wheat, but consume little or no soybeans (Krapu et al., 2004); soybean data are included because this crop accounts for a large proportion of crop land use, and weeds and weed seeds in harvested fields may be taken by geese (Alisauskas \& Ankney, 1992). The states listed for each crop are those where production and area of cultivation are highest and they include geographical areas used by wintering and migrating Mid-Continent Population snow geese. Total land area planted with corn and wheat has shown little overall change during the last 50 years, unlike the area devoted to rice which rose from 1950 to 1975 then stabilized, but the area of soybean production has risen threefold over the same period. However, these values mask differences among states during this period (e.g. Louisiana: increased corn plantings and decreased rice production in the last two decades). The area planted to corn in states where the Mid-Continent Population winters or visits on migration is twice the area planted with rice (Figs 2 and 3). Krapu et al. (2004) provide a crop land-use map for the Central and Mississippi Flyways (their Fig. 1).

In contrast to trends in area planted, yields of all four crops have increased substantially in the last 50 years. Increases are of the order of 3.5-fold for corn, 2.5-fold for rice, twofold for wheat and 6.5-fold for soybean (Figs 2-3), and are the result of the introduction of highyielding varieties and the application of nitrogenous (N) fertilizers, in particular. The use of $\mathrm{N}$ fertilizers in the United States increased substantially from 1965 to 1985, but the total amount applied to agricultural land has levelled off in the last decade at about $1.09 \times 10^{9} \mathrm{~kg}$. Lanyon (1995) has shown that there are substantial regional differences in fertilizer use. For example, in 1990, about $40 \%$ of total $\mathrm{N}$ fertilizer used for crop production in the US was on agricultural land in the 
Corn planted

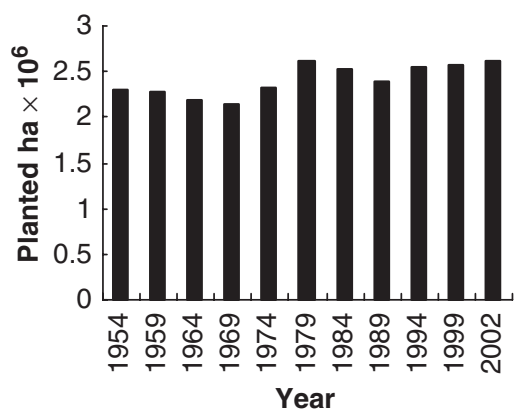

Rice planted

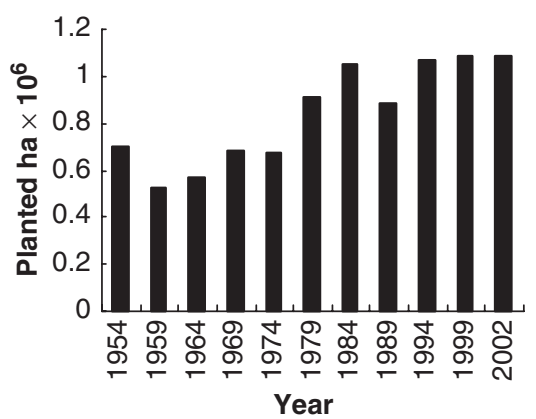

Corn harvested

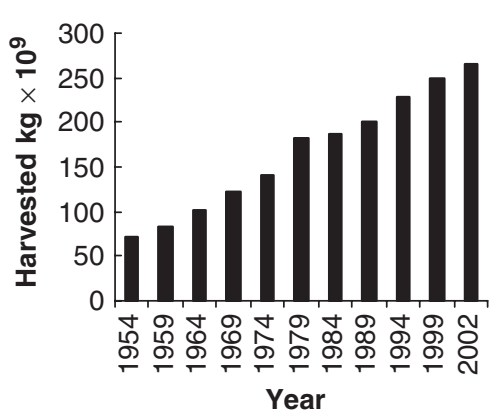

Rice harvested

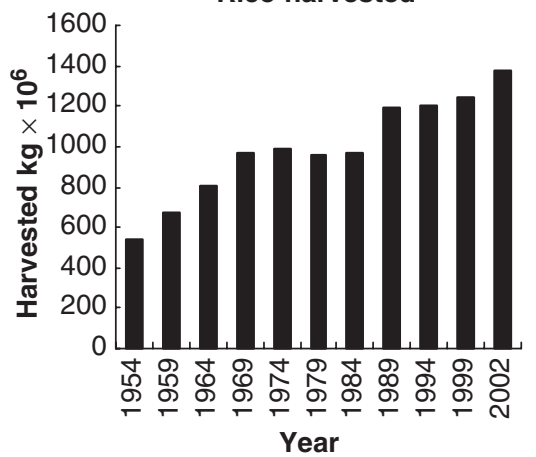

$\mathbf{N}$

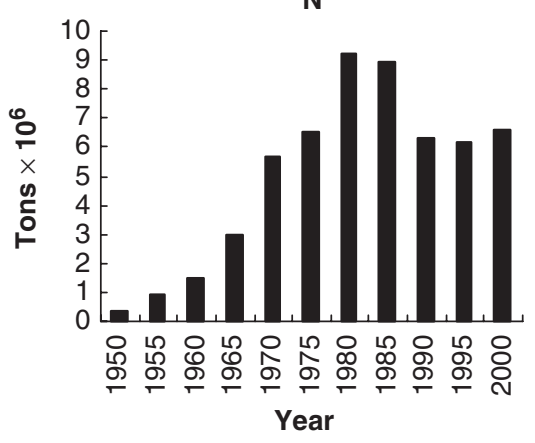

N

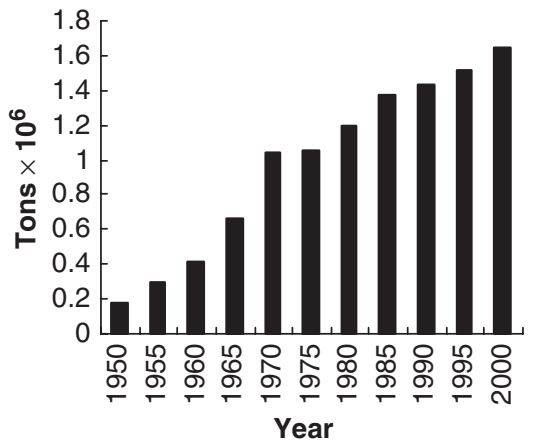

Fig. 2 Five-year averages 1950-2002 of corn hectares planted, corn kilograms harvested, and N fertilizer applied in the north-central United States (IA, IL, IN, KS, MI, MN, MO, ND, NE, OH, SD, WI), and rice hectares planted, rice kilograms harvested, and $\mathrm{N}$ fertilizer applied in the south-central United States (LA, TX, MS, AR, MO).

north central states and in Texas, compared with only $20 \%$ in 1940. Much of this fertilizer is used for corn production (Lanyon, 1995). Not surprisingly, spilled corn is one of the primary food sources of lesser snow geese (Alisauskas et al., 1988; Alisauskas \& Ankney, 1992; Krapu et al., 2004).

Such regional scale changes in agricultural land use may be expected to influence goose movements at the same regional scale. A comparison of the distribution and density of the Mid-Continent Population of snow geese on the wintering grounds, based on mid-winter surveys of birds for 1981-1985 and 2001-2004, is shown in Fig. 4. Although there has been some change in relative distribution over the last 20 years, there is little evidence of a northward movement of birds beyond areas occupied in the early 1980s, by which time 30 years of expansion had occurred. In contrast, densities of birds have increased substantially, particularly in rice-growing areas in the southern Mississippi valley and in states of the northern corn-belt.

The extensive network of U.S. National Wildlife Refuges, both on the wintering grounds and along migration routes of the Mid-Continent Population snow geese, is shown in Fig. 5. The national system was created in the 1930s and over 1.5 million hectares are included in refuges in the Mississippi Flyway and eastern Central Flyway, many of which are currently frequented by Mid-Continent Population lesser snow geese. Of those, 59\% were established after 1954 (USFWS data). This broadly coincides with major changes in agricultural practices and land use outlined above. Additionally, there are many state wildlife management areas and refuges and some private sanctuaries (Lynch, 1975; Bateman et al., 1988). Besides protection from hunters, refuges provide food for birds, in landscapes that include large wetland complexes adjacent to agricultural fields (USFWS, 2001). At some refuges (e.g. Bosque del Apache, NM), goose movements between agricultural land and refuges are jointly controlled by agricultural and wildlife officers to manage goose populations as efficiently as possible in order to meet various interests (farming, wildlife conservation, tourism and hunting) (Taylor \& Kirby, 1990).

Before conversion of mid-continent North America to agriculture, Arctic breeding Mid-Continent Population snow geese would have needed to find natural sites all along the migration routes and on wintering areas with sufficient green vegetation, seeds and below-ground aquatic plant parts as sources of protein and carbohydrate. Annual weather variations, including drought, likely rendered availability and nutritional quality of 


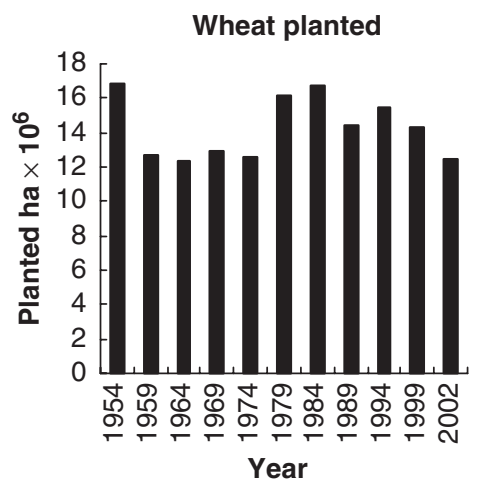

Soybean planted

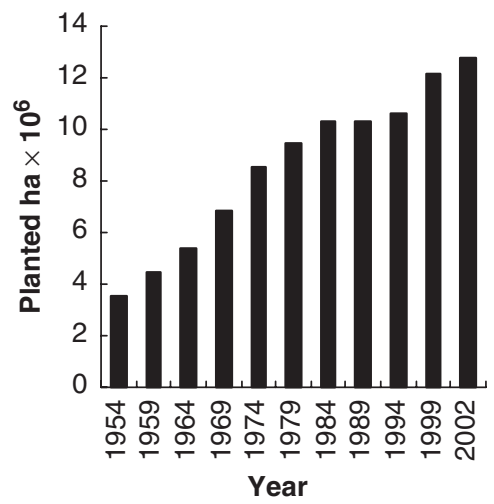

Wheat harvested

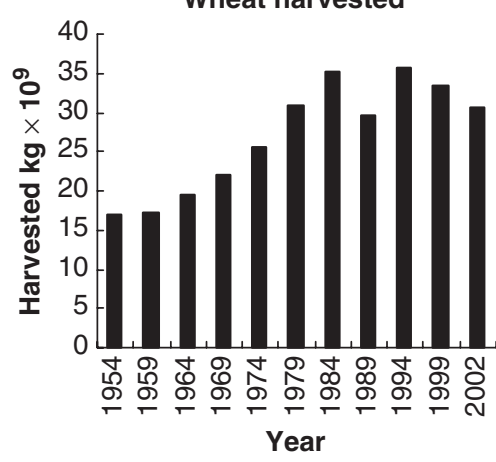

Soybean harvested

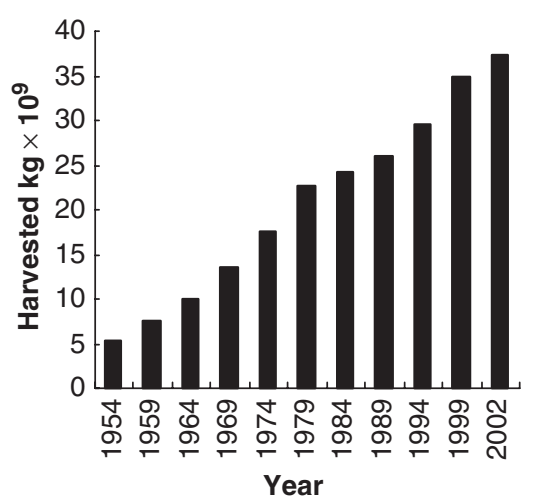

$\mathbf{N}$

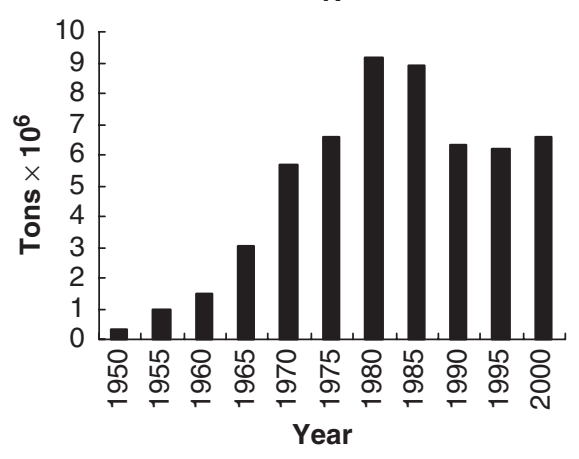

$\mathbf{N}$

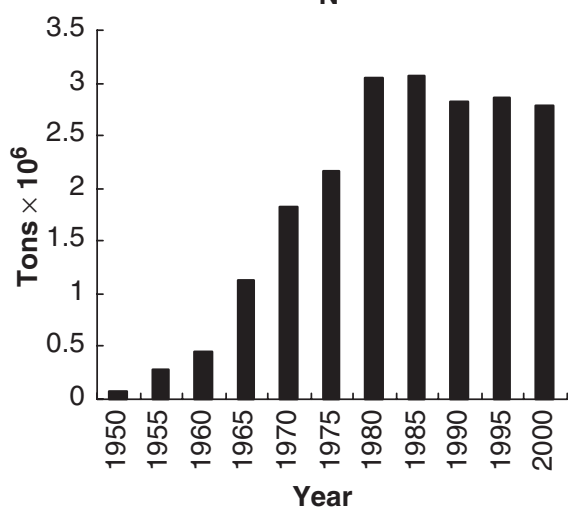

Fig. 3 Five-year averages 1950-2002 of wheat hectares planted, wheat kilograms harvested, N fertilizer applied in the north-central United States (IA, IL, IN, KS, MI, MN, MO, ND, NE, OH, SD, WI), soybean hectares planted, soybean kilograms harvested, and N fertilizer applied in the mid-west United States (IA, IL, IN, OH).

such foods unpredictable in space and time. Growth in the number and area of refuges has occurred concurrently with increasing crop yields, providing more spilled grain despite increased harvesting efficiency, and has resulted in a network of landscapes which are highly favored by snow geese, that has extended northward into southern Canada. Most snow geese no longer depend on habitats used historically, but use agricultural lands in which suitable habitat and food were previously unavailable (Lynch et al., 1947; Lynch, 1975; Alisauskas et al., 1988; Bateman et al., 1988; Krapu et al., 1995, 2004). They exploit differences in the annual and seasonal phenology of forage plants and in grain availability between sites with less energy expenditure than previously (Frederick \& Klaas, 1982; Alisauskas \& Ankney, 1992). Increased flexibility in movements of birds, particularly accelerated by land use changes since the mid-1900s, has led to shifts in migratory pathways. Such shifts are reasonably well documented at larger (flyway) scales (Alisauskas et al., 1988; Alisauskas, 1998) and at local scales (Widner \& Yaich, 1990), but much less information on goose movements and foraging is available at regional or intermediate scales (but see Krapu \& Schultze, unpublished results). This has resulted in more frequent stop-overs and reduced long-haul migration between breeding and wintering areas (Johnsgard, 1974; Dzubin et al., 1975; Francis \& Cooke, 1992). Consequently, Mid-Continent snow geese now are less vulnerable to unpredictable climatic vicissitudes than when they migrated over longer distances to fewer staging or winter sites (Alisauskas, 2002; Krapu \& Schultze, unpublished results).

\section{Energy and nutrient demands for migration and reproduction}

Studies by Ryder (1970) and Ankney \& MacInnes (1978) of Ross's and lesser snow geese showed that nutrient reserves acquired on the wintering grounds and on migration provide females with endogenous resources largely sufficient for egg formation and incubation in the Arctic. Building on these studies, Drent \& Daan (1980) introduced the terms 'capital' and 'income' breeders to describe sources of nutrients used for breeding by migratory birds. Capital breeders rely on resources obtained on the wintering grounds or along 

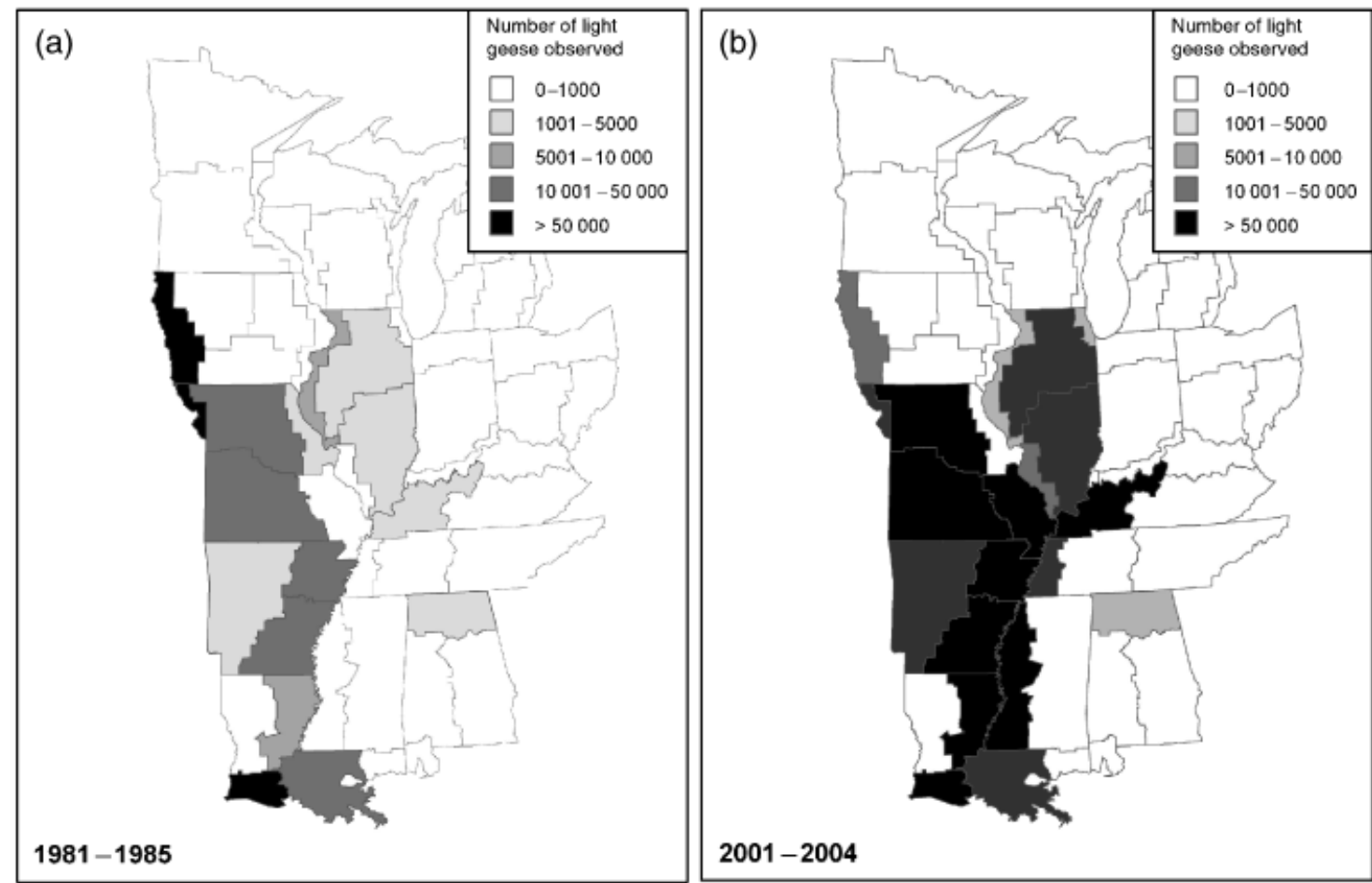

Fig. 4 Distribution and average numbers of mid-continent white geese observed in the Mississippi Flyway mid-winter waterfowl survey during 1981-1985 (a) and 2001-2004 (b). Data and map from Central and Mississippi Flyways, courtesy of David Fronczak, US Fish \& Wildlife Service, Columbia, MO.

the migration route for egg production, whereas income breeders gather resources for egg production directly from the breeding grounds. Whether or to what extent an Arctic-nesting species is an income or a capital breeder, depends very much on the relationship between body mass, egg mass, latitude, and migration distances and a continuum exists (Klaassen, 2003). Lesser snow geese may not be exclusively capital breeders. On Akimiski Island, Nunavut (Fig. 6), where the arrival to nesting interval is several days, a stable isotope study indicates that lesser snow goose gosling tissues were derived from both endogenous (stored reserves from southern latitudes) and exogenous (consistent with acquisition in northern latitudes) (Klaassen, 2003). Ganter \& Cooke (1996) reported substantial foraging by females both in the pre-laying phase and during incubation at La Pérouse Bay, Manitoba (Fig. 6) where arrival to nesting intervals also is several days (Cooke et al., 1995). In contrast, there was limited foraging at McConnell River (Ankney \& MacInnes, 1978) where arrival to nesting interval was 2-3 days, and there was limited food ingestion at Queen Maud Gulf despite apparent attempts to feed (Gloutney et al., 2001). Meijer \& Drent (1999) calculated from Ankney \& MacInnes (1978) that, depending on clutch size, between $14 \%$ and $55 \%$ of egg protein and
$46-70 \%$ of the fat required for egg formation and body metabolism in lesser snow geese were derived from reserves. Thus, a substantial percentage of certain nutrients used in egg formation can come from Arctic food sources. This intraspecific variability is likely an outcome of the variation in availability and nutritional quality of forage at wintering, staging, and breeding sites, that, in turn, is dependent on local weather conditions, seasonal phenology of forage plants in a given year, and (for breeding areas) past history and intensity of use by geese. Alisauskas (2002) demonstrated an ecological link between annual ratios of young to adult snow geese of the Mid-Continent Population each fall and the fat reserves of birds measured during the previous spring migration across southern Manitoba. Staging there represents the culmination of increasing hyperphagia along the extreme northern agricultural zones of Canada (Alisauskas \& Ankney, 1992), where most increase in body mass is the result of fat storage. Similar conclusions have been documented about the effects of late winter and early spring nutrition on the reproductive performance of pink-footed geese (Anser brachyrynchus), barnacle geese (Branta leucopsis A.O.U.), and brent geese (B. bernicla A.O.U.) in Europe (Prop \& Black, 1998; Madsen, 2001; Drent et al., 2003). Under the influence of annual 


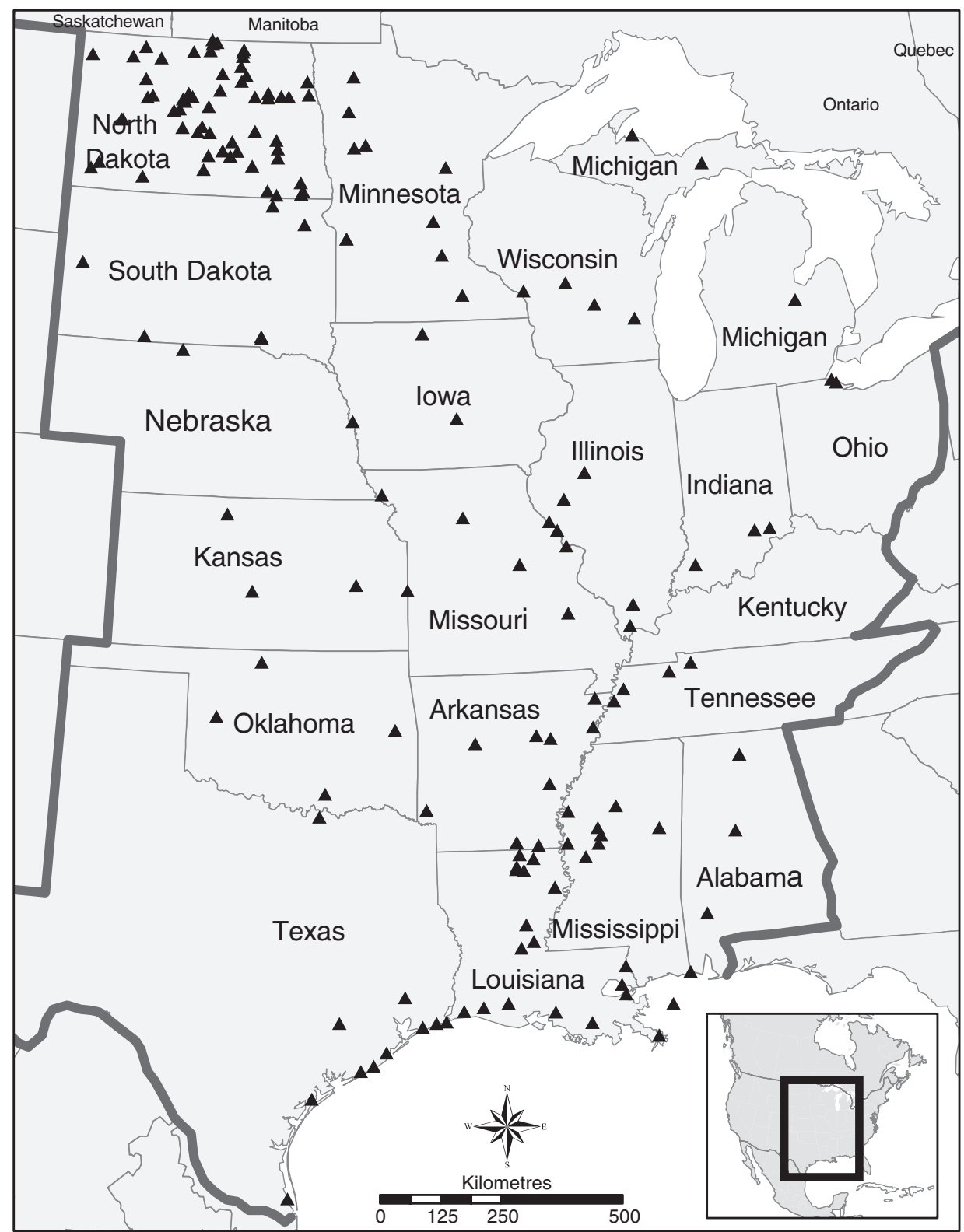

Fig. 5 National Wildlife Refuges in the wintering and migration ranges of mid-continent lesser snow geese. Data from US Fish \& Wildlife Service. Map courtesy of Kevin Middel, Ontario Ministry of Natural Resources.

variation in Arctic weather and nesting conditions, use of stored nutrient reserves by lesser snow geese appears to be of utmost importance in governing the annual production of young, thus influencing the potential for population growth.

During fall and winter, the dynamics of food availability and diet selection of snow geese vary within and between marsh and cropland habitats and differ depending on the time of year and the nutritional requirements of the geese (Prevett et al., 1979; Alisauskas et al., 1988). In rice fields during winter, green shoots $(87 \%)$, seeds $(7 \%)$, and subterranean organs $(4 \%)$ of rice are eaten, whereas in cornfields, much of the consumption is spilled grain (88\%), rather than green shoots $(10 \%)$. A diet of green shoots contains proportionately more protein, but less digestible carbohydrate than one of spilled corn (Alisauskas et al., 1988). In late winter and early spring, the birds primarily forage on a mixture of green plants, including sprouting grain, dicotyledonous weeds and seeds in order to build up protein reserves (Alisauskas \& Ankney, 1992). However, as they migrate north, spilled corn and the 


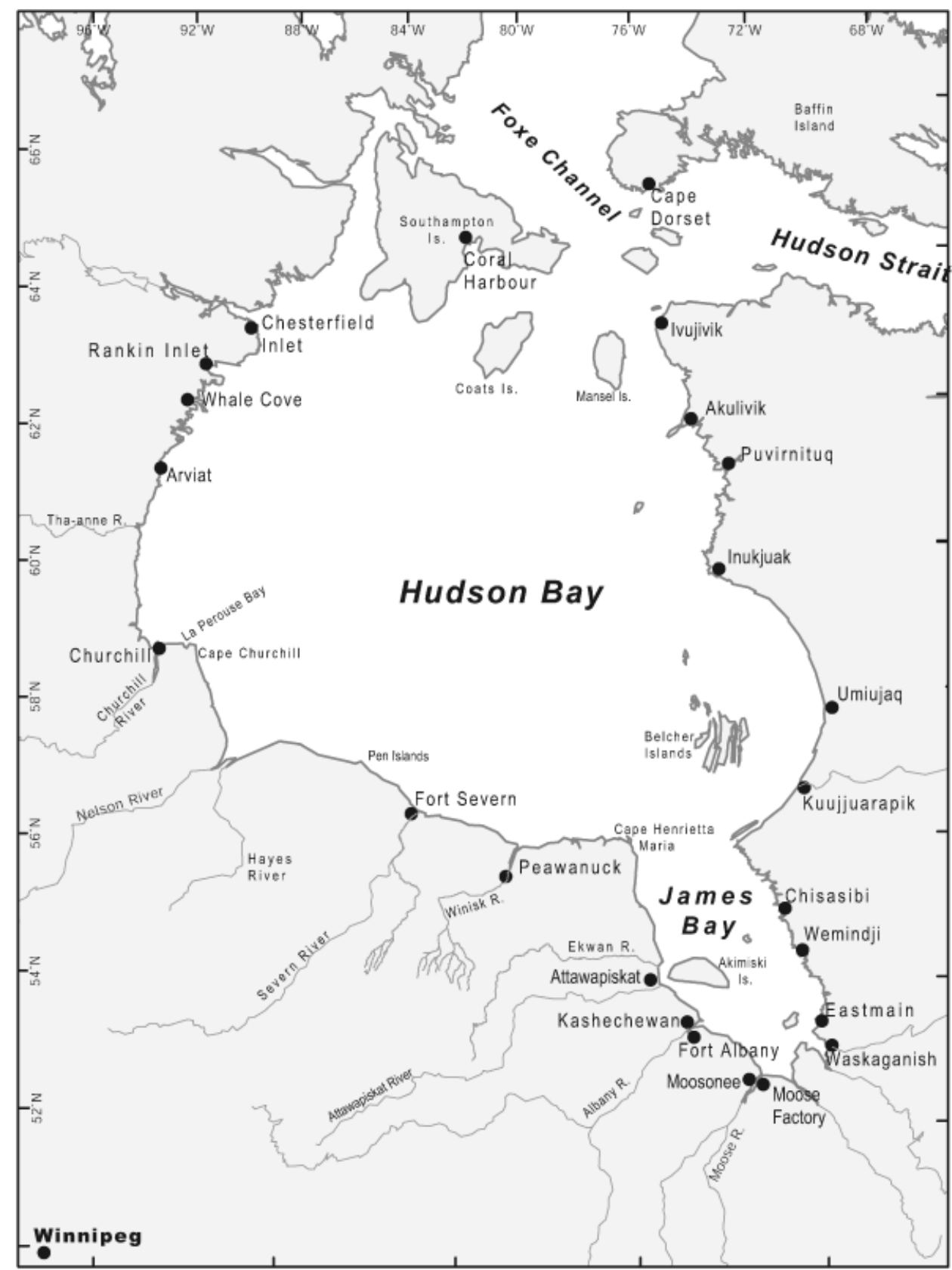

Fig. 6 Map of the James Bay-Hudson Bay-Foxe Channel region of eastern Canada.

underground organs of aquatic plants, which are rich in carbohydrates and permit the build up of fat, become an increasing proportion of the diet (Prevett $e t$ al., 1985; Alisauskas, 1988, 2002; Alisauskas \& Ankney, 1992). Fat is critical for final stages of migration. For example, female and male geese utilized an estimated 77-104 and $120-140 \mathrm{~g}$ of fat, respectively, on migratory flights from southern Manitoba to the Hudson Bay coast near Peawanuck, Ontario (Fig. 6), in 1983 and 1984, a distance of $900 \mathrm{~km}$ (Alisauskas, 1988). In these final staging areas on coastal Hudson Bay wetlands, feeding that occurs before egg laying and incubation appears to be linked to a second phase of protein storage (Wypkema \& Ankney, 1979; Alisauskas \& Ankney, 1992) replacing nutrients partially depleted during migration. The overall gain in protein and lipid from northern habitats is equivalent to the production of almost an additional egg; the birds may also increase intakes of calcium and sulphur in these habitats (Gloutney et al., 2001). The birds also acquire high 
amounts of soluble carbohydrates from swollen shoot bases of some dicotyledonous plants (e.g. Senecio congestus $100-200 \mathrm{mg}$ of hexose equivalents per gram dry weight of shoot tissue, R. L. Jefferies, unpublished data). Thus, where conditions permit, there should be a reproductive advantage to supplementing endogenous reserves with locally acquired nutrients.

Greater snow geese (Chen caerulescens atlanticus A.O.U.) migrate long distances $(2700 \mathrm{~km})$ between their final staging areas and breeding grounds, so considerable feeding before egg-laying to replenish reserves used during spring migration is predictable (Gauthier \& Tardif, 1991). In an elegant study, Gauthier et al. (2003) used the naturally occurring stable isotopes of carbon $\left(\delta^{13} \mathrm{C}\right)$ and nitrogen $\left(\delta^{15} \mathrm{~N}\right)$ in a quantitative mixing model to determine the percentage contribution of endogenous reserves to egg formation in greater snow geese. The results showed that only $22-33 \%$ of egg protein and less than $25 \%$ of egg lipid were derived from lower latitudes; the remainder was derived from latitudes similar to those where breeding occurs. Although measurements were made in 2 successive years when very different weather conditions prevailed, the contribution of the endogenous reserves to egg formation was similar.

Short-haul flights along mid-latitude migration corridors linked to acquisition of readily available agricultural food supplies do not appear to have completely alleviated the need for further feeding in Arctic wetlands. This suggests that the agricultural food subsidy, although reducing uncertainty of the availability of food supplies for migration and reproduction, does not necessarily lead to the build up of sufficient endogenous reserves to release Arctic wetlands from the effects of destructive pre-laying and nesting foraging behaviour. It also implies that agricultural foods may lack essential nutrients, such as amino acids needed for reproduction, as suggested by Prop \& Black (1998) for staging barnacle geese in Norway. Damage to Arctic vegetation from shoot-pulling and grubbing documented in southern Hudson Bay (Abraham \& Jefferies, 1997; Jefferies et al., 2003), which is compounded by increasing numbers of lesser snow geese, is likely to become more evident north of $60^{\circ} \mathrm{N}$, where the geographical centre of the nesting distribution of the Mid-Continent Population has shifted. Intertidal and freshwater vegetation cannot be sustained where high densities of nesting geese $\left(>1000\right.$ nests $\left.\mathrm{km}^{-2}\right)$ are present over many years. Birds arriving early at the breeding grounds may be expected to cause much more local damage than late birds, which nest quickly after arrival and are likely to use a greater percentage of endogenous reserves for egg formation (cf. Gauthier et al., 2003).

\section{The consequences for coastal Arctic and sub-Arctic vegetation}

Coastal sites in the southern Hudson Bay and James Bay are used extensively by both staging and breeding Mid-Continent Population snow geese, whereas sites north and north-east of Hudson Bay around Foxe Basin (Fig. 6) are used primarily by breeding birds. From the early 1950s to the mid-1990s, a trend toward colder temperatures and later spring thaws in the more northern breeding areas coincided with increasing numbers of geese in the Mid-Continent Population (Boyd \& Madsen, 1997; Skinner et al., 1998). This resulted in large numbers of birds extending their stopover in the southern Hudson Bay and James Bay coastal marshes, bringing more foraging pressure with less annual respite for the vegetation to recover. In early spring, after the surface layer of ground has thawed, but before the growth of above-ground vegetation, snow geese grub for roots and rhizomes of preferred saltmarsh graminoids which are a prime forage source in summer during the posthatch brood-rearing period (Prevett et al., 1985; Jefferies et al., 2003). This grubbing acts as a trigger for a feedback process with both biotic and abiotic components. Near-irreversible changes in sediments of intertidal marshes include hypersalinity in summer, compaction of sediment, lower infiltration rate, and loss of soil $\mathrm{N}$ and organic matter (Srivastava \& Jefferies, 1996; McLaren \& Jefferies, 2004). Increased evaporation from exposed sediment occurs, which draws inorganic salts to the surface from underlying marine clays. On occasions, soil salinity of exposed sediment in mid-summer can be three times that of seawater (Iacobelli \& Jefferies, 1991). This leads to the loss of intertidal salt-marsh swards and death of willow bushes in the supratidal marsh (Iacobelli \& Jefferies, 1991; Srivastava \& Jefferies, 1996). Re-establishment of the two preferred forage graminoids in salt marsh depends strongly on vegetative and clonal growth: the stoloniferous grass (Puccinellia phryganodes) is asexual, and the rhizomatous sedge (Carex subspathacea), rarely sets seed. Adverse soil conditions depress clonal growth and ability of such plants to establish from vegetative fragments produced by foraging geese (Chou et al., 1992; Srivastava \& Jefferies, 1995, 1996; McLaren \& Jefferies, 2004). It is very difficult for tillers of the grass to root in these consolidated, degraded soils, shown by experiments where successful establishment was not possible without first amending the soil with mulch and fertilizer (Handa \& Jefferies, 2000). Reestablishment of graminoid vegetation in the current degraded system depends on the presence of unconsolidated soft sediment in which the fragments can root. Such sites are not common and are usually located in 
river channels, or are seaward of existing sediments (Handa et al., 2002). Other plants disappear because of a decline in viability of seeds remaining in the soil, the absence of a seed rain because of loss of vegetation, and because erosion of the organic-rich surface layer of sediment results in the loss of an effective seed bank (Chang et al., 2001). Exclosures erected on exposed sediment in 1982 at La Pérouse Bay, Manitoba, are still devoid of vegetation in 2004.

A similar loss of vegetation occurs in freshwater sedge meadows of the Hudson Bay Lowland, immediately inland from the intertidal flats, as a result of shootpulling of sedges, especially Carex aquatilis, by snow geese. Where the ground has thawed sufficiently in spring, geese pull up shoots and consume their basal portions. The annual loss of shoots weakens the plants which eventually die, thereby exposing underlying peat or moss cover. In most summers, the exposed surface dries out and oxidation, together with wind and water erosion, ultimately results in loss of peaty material and exposure of the mineral base (marine clay, glacial gravels, calcareous marls).

The cumulative loss of patches of intertidal vegetation at a local scale creates a homogeneous landscape at a larger spatial scale as a result of the coalescence of areas of exposed sediment. These changes can be detected in LANDSAT imagery, where either spring staging concentrations and nesting by lesser snow geese occur, such as La Pérouse Bay (Jano et al., 1998), or where nesting colonies of hundreds of thousands occur, such as south of Queen Maud Gulf (Didiuk et al., 2001). The result is that the vegetated intertidal marsh has been lost at many sites along the Hudson Bay and James Bay coasts. This loss of an ecological sere is an outcome similar to the desertification in the Sahel (cf. Sinclair \& Fryxell, 1985; Graetz, 1991). Where the freshwater sedge meadows are also heavily damaged, such as on the west Hudson Bay coast near the former McConnell River (Fig. 6) goose colony (similarly detectable on LANDSAT imagery), the situation is the more severe because both the salt and freshwater plant communities are affected (Kerbes et al., 1990). The Hudson Bay region is undergoing isostatic uplift at a rate of $0.8 \mathrm{~cm} \mathrm{yr}^{-1}$ (Hansell et al., 1983) in the Churchill region. Salt-marsh graminoids should colonize the new shoreline that arises as a result of this process, but with current goose population levels, the foraging activities of the geese remove the vegetation so that graminoid swards fail to develop leading to exposed sediment and marine gravel on the surface of the shore (Handa et al., 2002).

The long-term decline since the mid-1970s in the quality and availability of intertidal salt-marsh vegetation at La Pérouse Bay has affected adversely the fitness components of the local La Pérouse Bay goose population (Cooke et al., 1995; Cooch et al., 2001). Adverse effects include a decline from 1973 to 1992 of clutch size from 4.3 to 3.4 , and a decline in mean annual body mass, tarsus, and culmen length of pre-fledged goslings of approximately $16 \%, 4 \%$, and $2 \%$, respectively, in goslings hatching between 1976 and 1988 which resulted in a similar decrease in the size of locally hatched adults (Cooch et al., 1991). Goslings reared at La Pérouse Bay by the same individual adult female in successive years showed a decline in size. In contrast, the body mass of goslings reared elsewhere on the Cape Churchill Peninsula (Fig. 6) did not decline (Cooch et al., 1993). In that study, the decrease was not related to hatch date, egg or hatch mass, or weather conditions during the brood-rearing phase. These results strongly suggest that the declines reflected a nongenetic change in gosling growth rates consistent with resource limitation during the posthatch phase (Cooch et al., 1991). Mean annual survival of young ringed just before fledging (0.42) declined from 1970 (0.60) to 1987 (ca. 0.30) (Francis et al., 1992).

Lesser snow geese no longer nest in any numbers in the original colony site on the shores of La Pérouse Bay where most of the habitat is degraded. They nest elsewhere on the Cape Churchill Peninsula where better vegetation is present, which has allowed an overall local population increase in response to higher adult survival. Families of Ross's geese and Canada geese now feed on the original (now degraded) intertidal flats of La Pérouse Bay during the posthatch period and outnumber family groups of lesser snow geese (Pezzanite, 2003). Similar changes occurred on the west coast of Hudson Bay in the 1970s and 1980s (MacInnes \& Kerbes, 1987; Kerbes et al., 1990). The adverse events described above take place at the local scale and have not limited the overall population growth occurring at the landscape scale as a result of food subsidies, and so far, availability of new breeding habitats to exploit.

Similar effects of grubbing and shoot-pulling are evident elsewhere. At Karrak Lake, south of Queen Maud Gulf, Nunavut, where both lesser snow geese and Ross's geese nest and forage during the posthatch period, vegetative cover of dry heath tundra in the nesting area has declined over the last 20 years (Alisauskas et al., unpublished results). The longest occupied Ross's and snow goose nesting areas had the lowest estimates of vegetative diversity and the largest proportion of damaged habitat. On the west side of Karrak Lake, a considerable area of exposed peat is evident from LANDSAT imagery (Didiuk et al., 2001). On the west coast of the Hudson Bay, the intertidal marshes from the McConnell River northwards to the 
Maguse River have largely disappeared (Kerbes et al., 1990). The loss of intertidal vegetation in the vicinity of the estuary of the McConnell River, where a large colony of snow geese nested (MacInnes \& Kerbes, 1987), appears to have occurred much earlier (1970s) than that at La Pérouse Bay. Lesser snow geese have since declined there and Ross's geese have increased because of global population expansion and immigration and are now the most abundant goose in the immediate coastal habitat (Didiuk et al., 2001). Although the foraging behaviour of Ross's geese compared with lesser snow geese is not well understood, the smaller species has a shorter development period to fledging, a faster pecking rate and the smaller bill size that allows the birds to clip vegetation that lies very close to the soil surface (Pezzanite, 2003). This may largely account for the ability of Ross's geese to acquire sufficient plant resources on degraded intertidal flats.

Loss of vegetation and deterioration of coastal habitats have affected other taxa besides vascular plants and geese. Abundance of soil invertebrates species declined, and some species were lost, particularly spiders and beetles that are an important food source for passerines (Milakovic et al., 2001). Similar trends are evident in the midge populations (Chironomidae) that occur in the brackish shallow vernal ponds in the supratidal marsh. Ponds in the undamaged marsh contain five species from five genera, while hypersaline ponds in the degraded supratidal marsh are represented by only one species (Milakovic \& Jefferies, 2003). At one study area (7 ha) at La Pérouse Bay, a decline of $63 \%$ in vegetative cover in the past 25 years has led to a decline of $77 \%$ in the numbers of nesting pairs of savannah sparrows (Passerculus sandwichensis A.O.U.) from approximately $3.5-0.8$ nests $^{-1} \mathrm{a}^{-1}$, because of the unavailability of grass for nest construction and willow bushes for concealment (Rockwell et al., 2003). Similar declines of some shorebird species have occurred at these sites (R. F. Rockwell, pers. comm.).

The evidence provides an overwhelming case that where lesser snow geese occur at high densities for much of the snow-free season over many years, local vegetation and land cover will be adversely impacted. At sites where this occurs, there is a cascade of effects on different ecosystem processes which have resulted in loss of species richness at the local level (Handa et al., 2002; Jefferies et al., 2003, McLaren \& Jefferies, 2004).

\section{Imposing constraint through liberalized hunting}

The geometric increase in the Mid-Continent Population of lesser snow geese is estimated to have been between $5 \% \mathrm{yr}^{-1}$ and $7 \% \mathrm{yr}^{-1}$ between the late 1960s and mid-1990s (Cooke et al., 1995; Abraham et al., 1996).
Because this increase may be expected to have a substantial effect on the sustainability of ecosystems in the sub-Arctic and Arctic, particularly in the vicinity of breeding colonies, the Governments of the United States and Canada in 1999 introduced a special spring hunt and modified regular hunting season regulations to increase or eliminate daily bag limits. Regulatory changes were designed to reduce numbers of snow geese in the Mid-Continent Population (USFWS, 2001) and greater snow geese in eastern North America. Previously, regulations under the Migratory Bird Convention between the US, Canada, and Mexico, restricted nonaboriginal hunting of lesser snow geese to autumn and early winter (September-February) with restrictive daily bag limits. The objective of wildlife agencies from both countries is to reduce annual growth rate of the goose population below the replacement rate $(\lambda)$ of 1 to achieve a reduction of the population to approximately $50 \%$ of its size in the mid-1990s over 10 years (Rockwell et al., 1997; USFWS, 2001). Adult snow geese have a mean life expectancy of about 7 years and they do not breed until they are 2 or more years of age. In a simulation of the impacts of reductions in survival and fecundity, Rockwell et al. (1997) showed that adult female survival made the greatest contribution to the growth rate of the population. The harvest rate necessary to achieve a replacement rate less than 1 has generated considerable discussion, partly because of uncertainty over current values for different population parameters (Cooke $e t$ al., 1999; Rockwell \& Ankney, 1999). Output from the simulation shows that when the population was reduced by a fixed number (1.41 million) each year for 5 years, the annual growth rate $(\lambda)$ fell from 0.94 to 0.71 and the estimated autumn population declined from 8.33 million to 3 million (Rockwell \& Ankney, 1999). The number of geese from the Mid-Continent Population actually harvested since the introduction of the expanded seasons has increased from 0.6 million in 1998 to 1.4 million in 2001 (Kruse \& Sharp, 2002). If this level of harvesting is sustained and the estimates of population size, survival and fecundity are correct, then the planned reduction of $50 \%$ of the target population may be achieved.

Another aspect of the spring hunt is the increased harassment of birds at staging sites in the United States and Canada. Mainguy et al. (2002) have examined the reproductive success of radio-collared greater snow geese before and after the introduction of the spring hunt in 1999. Most marked birds failed to breed successfully. They reported all other factors between the two periods as nonsignificant including the weather. Although a number of explanations of the cause of the decline are possible, the inability of birds to obtain 
sufficient fat and protein reserves at staging sites on agricultural land, because of harassment from farmers and/or hunters is a realistic explanation (cf. Madsen \& Fox, 1997; Madsen, 1998; Mainguy et al., 2002). Recently, Drent et al. (2003) have reported that the harassment of pink-footed geese (A. brachyrhynchus) by farmers on the Norwegian island of Vesterålen affects abdominal fat accumulation at this staging site. When the accumulation is low in spring, birds fail to return in autumn with goslings. Similarly, Mainguy et al. (2002) showed that adult greater snow geese contained less abdominal fat in years after introduction of the spring hunt than before. In addition, egg laying in the colony on Bylot Island, Nunavut was delayed 1 week in the 3 years after 1999 compared with the 4 previous years, independent of the extent of snow cover on the island. This disturbance effect has not yet been demonstrated for mid-continent lesser snow geese.

The effects of the initiative to reduce Mid-Continent Population lesser snow goose numbers are inconclusive at this stage (i.e. after 5 years). The mid-winter index survey showed a mean count of 2.7 million geese in the 5 years before the spring hunt commenced and a mean count of 2.4 million in the 5 years after the hunt (USFWS, 2004). Thus, the challenge for successful population management of mid-continent lesser snow geese remains.

\section{Caveat}

Agricultural polices on the North American Continent will continue to influence numbers of waterfowl as a result of changes in crop production. In a far-sighted study, Krapu et al. (2004) point out a number of recent changes in US agriculture that are likely to profoundly affect waterfowl populations during the coming decades and possibly lead to a reduction in wildlife populations. The US Federal Agriculture Improvement and Reform Act of 1996 provided a major incentive for farmers to expand soybean production because of a favourable assistance loan rate. In some mid-western states, the area planted with soybean now exceeds that of corn. Additionally, an increasing percentage of the soybean crop is genetically modified (75\% in 2002; Krapu et al., 2004) and the application of glyphosate limits weed growth and is contributing to the loss of the weed seed bank. Corn production (data from 2002) shows an estimated $34 \%$ of the crop is genetically modified and weed production has fallen. Although the quantity of spilled corn kernels has not declined, waste of whole ears has dropped sharply from 230 in 1978 to $49 \mathrm{~kg} \mathrm{ha}^{-1}$ in 1998 as harvest efficiency rates have improved to $99 \%$ in some localities (Krapu et al., 2004). The lack of green weedy forage, the reduced avail- ability of spilled corn and the near-avoidance of soybeans as a food source by birds indicate a general decline in food availability and an impending bottleneck of resources for wintering and migratory birds. Competition between different species of waterfowl for limited quantities of agricultural foods is likely to increase (Krapu et al., 2004). In turn, this will likely affect spring migration patterns, time spent at existing and possibly new staging sites, and adversely impact adult survival and reproductive success on the Arctic breeding grounds. Whether the Conservation Title of the US Farm Bill of 2002, which allows for incentives for farmers to grow high-energy foods for wildlife, will result in sufficient crop residues beneficial to wildlife, thereby removing the resource bottleneck, remains to be determined (Krapu et al., 2004).

\section{Acknowledgements}

We gratefully acknowledge financial and logistical support from the Ontario Ministry of Natural Resources, the Canadian Wildlife Service of Environment Canada and NSERC. We thank R. F. Rockwell, D. Abraham and A. Jano for review and assistance with earlier drafts, D. Fronczak, K. Gamble, D. Sharp for providing data, and K. Middel for creating Fig. 5. We also thank two anonymous reviewers for suggesting improvements.

\section{References}

Abraham KF, Jefferies RL (1997) High goose populations, causes, impacts and implications. In: Arctic Ecosystems in Peril: Report of the Arctic Goose Habitat Working Group. A Special Publication of the Arctic Goose Joint Venture of the North American Waterfowl Management Plan (ed. Batt BDJ), pp. 7-72. U.S. Fish and Wildlife Service, Washington, D.C. and Canadian Wildlife Service, Ottawa, Canada.

Abraham KF, Jefferies RL, Rockwell RF (1996) Why are there so many white geese in North America? In: Proceedings of the 7th International Waterfowl Symposium (ed. Ratti J), pp. 72-92. Memphis, Tennessee, USA.

Abraham KF, Leafloor JO, Lumsden HG (1999) Establishment and growth of the lesser snow goose, Chen caerulescens caerulescens, nesting colony on Akimiski Island, James Bay, Northwest Territories. Canadian Field Naturalist, 113, 245-250.

Alisauskas RT (1988) Nutrient reserves of Lesser Snow Geese during winter and spring migration. $\mathrm{PhD}$ thesis, University of Western Ontario, London, Ontario, Canada.

Alisauskas RT (1998) Winter range expansion and relationships between landscape and morphometrics of midcontinent lesser snow geese. $A u k, 115,851-862$.

Alisauskas RT (2002) Arctic climate, spring nutrition, and recruitment in mid-continent lesser snow geese. Journal of Wildlife Management, 66, 181-193.

Alisauskas RT, Ankney CD (1992) Spring habitat use and diets of midcontinent adult lesser snow geese. Journal of Wildlife Management, 56, 43-54. 
Alisauskas RT, Ankney CD, Klaas EE (1988) Winter diets and nutrition of midcontinental Lesser Snow Geese. Journal of Wildlife Management, 52, 403-414.

Ankney CD, MacInnes CD (1978) Nutrient reserves and reproductive performance of female lesser snow geese. Auk, 95, 459-471.

Bateman HA, Joanen T, Stutzenbaker CD (1988) History and status of midcontinental snow geese on their Gulf Coast winter range. In: Waterfowl in Winter (ed. Weller MW), pp. 495-515. University of Minnesota Press, Minneapolis, USA.

Boyd H, Madsen J (1997) Impacts of global change on Arctic breeding bird populations and migration. In: Global Change and Arctic Terrestrial Ecosystems (eds Oechel WC, Callaghan T, Gilmanov T, Holten JI, Maxwell B, Molau U, Sveinbjornsson B), pp. 201-217. Springer-Verlag, Berlin.

Boyd H, Smith GEJ, Cooch FG (1982) The lesser snow goose of the eastern Canadian Arctic: their status during 1964-1979 and their management from 1982 to 1990. Canadian Wildife Service Occasional Paper, 46, 1-21.

Chang ER, Jefferies RL, Carleton TJ (2001) Relationship between vegetation and soil seed banks in an arctic coastal marsh Journal of Ecology, 89, 367-384.

Chou R, Vardy C, Jefferies RL (1992) Establishment of leaves and other plant fragments produced by the foraging activities of geese. Functional Ecology, 6, 297-301.

Cooch EG, Jefferies RL, Rockwell RF et al. (1993) Environmental change and the cost of philopatry: an example in the lesser snow goose. Oecologia, 92, 1-11.

Cooch EG, Lank DB, Rockwell RF et al. (1991) Long-term decline in body size in a snow goose population: evidence of environmental degradation? Journal of Animal Ecology, 60, 483-496.

Cooch EG, Rockwell RF, Brault S (2001) Retrospective analysis of demographic responses to environmental change: a lesser snow goose example. Ecological Monographs, 71, 377-400.

Cooch GC (1955) Observations on the autumn migration of blue geese. Wilson Bulletin, 67, 171-174.

Cooke F, Francis CM, Cooch EG et al. (1999) Impact of hunting on population growth of mid-continent Lesser Snow Geese. In: Population Modeling and Management of Snow Geese. Canadian Wildlife Service Occasional Paper: Number 102 (ed. Boyd H), pp. 17-31. Canadian Wildlife Service, Ottawa, Ontario, Canada.

Cooke F, Rockwell RF, Lank DB (1995) The Snow Geese of La Pérouse Bay. Oxford University Press, Oxford.

Didiuk AB, Alisauskas RT, Rockwell RF (2001) Interaction with arctic and subarctic habitats. In: The Status of Ross's Geese (ed. Moser TJ), pp. 19-32. Arctic Goose Venture Special Publication. U.S. Fish and Wildlife Service, Washington, D.C. and Canadian Wildlife Service, Ottawa, ON.

Drent R, Both C, Green M et al. (2003) Pay-offs and penalties of competing migratory schedules. Oikos, 103, 274-292.

Drent R, Daan S (1980) The prudent parent: energetic adjustments in avian breeding. Ardea, 68, 225-252.

Dzubin A, Boyd H, Stephen WJD (1975) Blue and Snow Goose Distribution in the Mississippi and Central Flyways, 1951-1971. Canadian Wildlife Service Progress Notes No. 54. Canadian Wildlife Service, Ottawa, Ontario, Canada.
Francis CM, Cooke F (1992) Migration routes and recovery rates of Lesser Snow Geese from southwestern Hudson Bay. Journal of Wildlife Management, 56, 279-286.

Francis CM, Richards MH, Cooke F et al. (1992) Long-term changes in survival rates of lesser snow geese. Ecology, 73, 1346-1362.

Frederick RB, Klaas EE (1982) Resource use and behavior of migrating snow geese. Journal of Wildife Management, 46, 601614.

Ganter B, Cooke F (1996) Pre-incubation feeding activities and energy budgets of snow geese: can food on the breeding grounds influence fecundity? Oecologia, 106, 153-165.

Gauthier G, Bêty J, Hobson KA (2003) Are greater snow geese capital breeders? New evidence from a stable-isotope model. Ecology, 84, 3250-3264.

Gauthier G, Tardif J (1991) Female feeding and male vigilance during nesting in greater snow geese. Condor, 93, 701-711.

Gloutney ML, Alisauskas RT, Afton AD et al. (2001) Foraging time and dietary intake by breeding Ross's and Lesser Snow Geese. Oecologia, 127, 78-86.

Graetz RD (1991) Desertification: a tale of two feedbacks. In: Ecosystem Experiments, Scope 45 (eds Mooney HA, Medina E, Schindler DW et al.), pp. 59-87. John Wiley, New York, USA.

Handa IT, Harmsen R, Jefferies RL (2002) Patterns of vegetation change and the recovery potential of degraded areas in a coastal marsh system of the Hudson Bay Lowland. Journal of Ecology, 90, 86-99.

Handa IT, Jefferies RL (2000) Assisted revegetation trials in degraded salt marshes of the Hudson Bay Lowland. Journal of Applied Ecology, 37, 944-958.

Hansell RIC, Scott PA, Staniforth RJ et al. (1983) Permafrost development in the intertidal zone at Churchill, Manitoba. A possible mechanism for accelerated beach uplift. Arctic, 36, 195-203.

Hanson HC, Lumsden HG, Lynch JJ et al. (1972) Population characteristics of three mainland colonies of Blue and Lesser Snow Geese nesting in the southern Hudson Bay region. Ontario Ministry of Natural Resources Research Report (Wildife), 92, 1-38.

Iacobelli A, Jefferies RL (1991) Inverse salinity gradients in coastal marshes and the death of Salix: the effects of grubbing by geese. Journal of Ecology, 79, 61-73.

Jano AP, Jefferies RL, Rockwell RF (1998) The detection of change by multitemporal analysis of LANDSAT data: the effects of goose foraging. Journal of Ecology, 86, 93-99.

Jefferies RL, Rockwell RF, Abraham KF (2003) The embarrassment of riches: agricultural food subsidies, high goose numbers, and loss of Arctic wetlands - a continuing saga. Environmental Reviews (National Research Council of Canada), 11, 193-232.

Jefferies RL, Rockwell RF, Abraham KF (2004) Agricultural food subsidies, migratory connectivity and large scale disturbance in Arctic coastal systems: a case study. Integrative and Comparative Biology, 44, 130-139.

Johnsgard PA (1974) Song of the North Wind: A Story of the Snow Goose. Anchor Press/Doubleday, Garden City, NY.

Kelley JR, Duncan DC, Yparraquirre DR (2001) Distribution and abundance. In: The Status of Ross's Geese (ed. Moser TJ), 
pp. 11-18. Arctic Goose Joint Venture Special Publication. US Fish and Wildlife Service, Washington, DC. and Canadian Wildlife Service, Ottawa, ON.

Kerbes RH (1975) The Nesting Population Of Lesser Snow Geese in the Eastern Canadian Arctic: A Photographic Inventory of June 1973. Canadian Wildife Service Report Series, Vol. 35, pp. 1-46. Canadian Wildlife Service, Ottawa, Canada.

Kerbes RH (1983) Lesser snow goose colonies in the western Canadian Arctic. Journal of Wildlife Management, 47, 523-526.

Kerbes RH, Kotanen PM, Jefferies RL (1990) Destruction of wetland habitats by Lesser Snow Geese: a keystone species on the west coast of Hudson Bay. Journal of Applied Ecology, 27, 242-258.

Kerbes RH, Meeres KM, Alisauskas RT et al. (2005) Inventory of nesting mid-continent lesser snow geese and Ross's geese in Eastern and Central Arctic Canada, 1997-98. In: Canadian Wildlife Service Technical Report (ed. Leafloor J), Canadian Wildlife Service, Winnipeg, Manitoba, Canada (in preparation).

Klaassen M (2003) Relationships between migration and breeding strategies in Arctic breeding birds. In: Avian Migration (eds Berthold P, Gwinner E, Sonnenschein E), pp. 237-249. Springer-Verlag, New York.

Krapu GL, Brandt DA, Cox RR. Jr (2004) Less waste corn, more land in soybeans, and the switch to genetically modified crops: trends with important implications for wildlife management. Wildlife Society Bulletin, 32, 127-136.

Krapu GL, Reinecke KJ, Jorde DG et al. (1995) Spring-staging ecology of mid-continent greater white-fronted geese. Journal of Wildlife Management, 59, 736-748.

Kruse KL, Sharp DE (2002) Central Flyway and Population Survey Data Book. Office of Migratory Bird Management, U.S. Fish and Wildlife Service, Denver, CO, USA.

Lanyon LE (1995) Does nitrogen cycle? Changes in the spatial dynamics of nitrogen with industrial nitrogen fixation. Journal of Production Agriculture, 8, 70-78.

Lynch JJ (1975) Winter ecology of snow geese on the Gulf Coast, 1925-1975. 37th Midwest Fish \& Wildlife Conference, Toronto, $\mathrm{ON}$.

Lynch JJ, O'Neil T, Lay DW (1947) Management significance of damage by geese and muskrats to Gulf Coast marshes. Journal of Wildlife Management, 11, 50-76.

MacInnes CD, Kerbes RH (1987) Growth of the snow goose, Chen caerulescens, colony at McConnell River, Northwest Territories: 1940-1980. Canadian Field-Naturalist, 101, 33-39.

Madsen J (1998) Changing trade-offs between predation risk and food intake: gaining access to feeding patches during springfattening in pink-footed geese Anser brachyrhynchus. In: Research on Arctic Geese. Proceedings of the Svalbard Goose Symposium (eds Mehlum F, Black JM, Madsen J), pp. 305-311. Norsk PolarInstitutt, Oslo, Norway.

Madsen J (2001) Spring migration strategies in pink-footed geese Anser brachyrynchus and consequences for spring fattening and fecundity. Ardea, 89, 43-55.

Madsen J, Fox AD (1997) Impacts of hunting disturbance on waterbird populations - the concept of flyway networks of disturbance-free areas. Gibier Faune Sauvage, 14, 201-209.
Mainguy J, Bety J, Gauthier G et al. (2002) Are body condition and reproductive effort of laying snow geese affected by the spring hunt? Condor, 104, 156-162.

Mcllhenny EA (1932) The blue goose in its winter home. Auk, 49, 279-306.

McLaren JR, Jefferies RL (2004) Initiation and maintenance of vegetation mosaics in an Arctic salt marsh. Journal of Ecology, 92, 648-660.

Meijer T, Drent RH (1999) Re-examination of the capital and income dichotomy in breeding birds. Ibis, 141, 399-414.

Milakovic B, Carleton TJ, Jefferies RL (2001) Changes in midge (Diptera:Chironomidae) populations of sub-arctic supratidal vernal ponds in response to goose foraging. Ecoscience, 8 , 58-67.

Milakovic B, Jefferies RL (2003) The effects of goose herbivory and loss of vegetation on ground beetle and spider assemblages in an Arctic supratidal marsh. Ecoscience, 10, 57-65.

Pezzanite B (2003) The foraging behavior of lesser snow geese and Ross's geese on La Pérouse Bay. PhD Thesis, City University of New York, New York, USA, 162 pp.

Prevett JP, Marshall IF, Thomas VG (1979) Fall foods of lesser snow geese in the James Bay region. Journal of Wildlife Management, 43, 736-742.

Prevett JP, Marshall IF, Thomas VG (1985) Spring foods of snow and Canada geese at James Bay. Journal of Wildlife Management, 49, 558-563.

Prop J, Black JM (1998) Food intake, body reserves and reproductive success of barnacle geese Branta leucopsis staging in different habitats. In: Research on Arctic Geese. Proceedings of the Svalbard Goose Symposium (eds Mehlum F, Black JM, Madsen J), pp. 175-193. Norsk PolarInstitutt, Oslo, Norway.

Rockwell RF, Ankney CD (1999) Snow geese: can we pay down the mortgage? In: Population Modelling and the Management of Snow Geese. Canadian Wildife Service Occasional Paper: Number 102 (ed. Boyd H), pp. 32-34. Canadian Wildlife Service, Ottawa, Ontario Canada.

Rockwell RF, Cooch EG, Brault S (1997) High goose populations: causes, impacts and implications. In: Arctic Ecosystems in Peril. Arctic Goose Joint Venture Special Publication (ed. Batt BDJ), pp. 73-100. U.S. Fish and Wildlife Service, Washington, DC. and Canadian Wildlife Service, Ottawa, ON.

Rockwell RF, Witte CR, Jefferies RL et al. (2003) Response of nesting savannah sparrows to 25 years of habitat change in a snow goose colony. Ecoscience, 10, 33-37.

Rusch DH, Malecki RE, Trost R (1995) Canada geese in North America. In Our Living Resources: A Report to the Nation on the Distribution, Abundance and Health of U.S. Plants, Animals and Ecosystems (eds LaRoe ET, Farris GS, Puckett CE, Doran PD, Mac MJ), pp. 26-34. US Department of Interior National Biological Service, Washington, DC.

Ryder JP (1970) A possible factor in the evolution of clutch size in Ross' goose. Wilson Bulletin, 82, 5-13.

Shrubb M (2003) Birds, Scythes and Combines: A History of Birds and Agricultural Change. Cambridge University Press, Cambridge.

Sinclair ARE, Fryxell JM (1985) The Sahel of Africa: ecology of a disaster. Canadian Journal of Zoology, 63, 987-994. 
Skinner WR, Jefferies RL, Carleton TJ et al. (1998) Prediction of reproductive success and failure in lesser snow geese based on early season climatic variables. Global Change Biology, 4, 3-16.

Soper JD (1942) Life history of the blue goose (Chen caerulescens caerulescens)(Linneaus). Proceedings of the Boston Society of Natural History, Vol. 42, pp. 125-222.

Srivastava DS, Jefferies RL (1995) Mosaics of vegetation and soil salinity: a consequence of goose foraging in an arctic salt marsh. Canadian Journal of Botany, 73, 75-83.

Srivastava DS, Jefferies RL (1996) A positive feedback: herbivory, plant growth, salinity, and the desertification of an arctic salt marsh. Journal of Ecology, 84, 31-42.

Taylor JP, Kirby RE (1990) Experimental dispersal of wintering snow and Ross' geese. Wildlife Society Bulletin, 18, 312-319.

US Fish \& Wildlife Service (2001) Draft Environmental Impact Statement: Light Goose Management, September 2001. US Department of the Interior, Washington, DC, USA.

US Fish \& Wildlife Service (2004) Waterfowl Population Status 2004. US Department of the Interior, Washington, DC, USA. van Eerden MR, Zijlstra M, van Roomen M et al. (1996) The response of Anatidae to changes in agricultural practice: longterm shifts in the carrying capacity of wintering waterfowl. Gibier Faune Sauvage, 13, 681-706.

van Roomen M, Madsen J (1992) Waterfowl and Agriculture: Review and Future Perspective of the Crop Damage Conflict in Europe. IWRB Special Publication No. 21. International Waterfowl and Wetlands Bureau, Slimbridge, UK.

Webster MS, Marra PP, Haig SM et al. (2002) Links between worlds: unraveling migratory connectivity. Trends in Ecology and Evolution, 17, 76-83.

Whitney GG (1994) From Coastal Wilderness to Fruited Plain: A History of Environmental Change in Temperate North America from 1500 to the Present. Cambridge University Press, Cambridge.

Widner MR, Yaich SC (1990) Distribution and habitat use of snow and white-fronted geese in Arkansas. Proceedings of the Annual Conference of Southeast Association of Fish and Wildlife Agencies, 44, 328-336.

Wypkema R, Ankney CD (1979) Nutrient reserve dynamics of lesser snow geese staging at James Bay, Ontario. Canadian Journal of Zoology, 57, 213-219. 